\title{
Scientific Excellence in Participatory and Action Research: Part I. Rethinking Research Quality
}

\author{
Erik Lindhult
}

\author{
In memory of Björn Gustavsen
}

\begin{abstract}
"Action research is not only one of a number of 'branches' or") competing 'schools of thought' but actually a main school... action research finds its legitimacy in an ability to deal with the traditional tasks of research in a way which is superior to other schools of thought.
\end{abstract}

Björn Gustavsen (1938-2018)

Professor and Action Researcher

In Gustavsen (1992)

\begin{abstract}
A core impetus of participatory and action research is making science relevant and useful for solving pressing problems and improving social conditions, and enabling stakeholders to participate in research and development processes. There are claims in the community of participatory and action research of the potential for heightened scientific excellence, but at the same time, there are critiques in the mainstream community that more engaged, even activist, stances threaten scientific norms or that position these type of research approaches outside the field of science, for example, as issues of application. In the search of clarification of the scientific identity and the specific qualities of participatory and action research, scholars have been moving away from and sometimes have rejected traditional conceptions of quality. This leads to confusion about how to relate to the discourse on research quality and scientific excellence in mainstream science. Integration in this discourse is important in order to attain academic legitimation in prevailing institutions of science, for example, in applications for funding, in seeking to publish research, and in the acceptance of dissertations based on participatory and action research. The purpose of this article is to contribute to this integration by reconstructing the way traditional quality concepts - validity, reliability, and objectivity - can be fruitfully used in expanded frameworks for quality where scientific excellence of participatory and action approaches are visible and where mainstream science approaches also can be harboured. In this conceptual article, reconstruction of understanding of scientific inquiry is first made based on a praxis-oriented epistemology inspired by pragmatism. Through rethinking truth as trustworthiness, new proposals for the conceptualization and frames for research quality and scientific excellence are introduced. Second, a framework for understanding purpose in science and its basis in validity, reliability, and the core characteristics of participatory and action research is developed. Third, the turn to action, practice, and participation enables plural ways of knowing and ways that knowledge claims can be validated and made trustworthy. The article concludes that participatory and action research offers a broader landscape of purpose and validation than more traditional approaches to science. In a subsequent article, reliability and objectivity, and their use in participatory and action research, will be clarified.
\end{abstract}




\section{Scientific Excellence in Participatory and Action Research: Part I. Rethinking Research Quality Erik Lindhult}

\section{Introduction}

The quality discourse in the scientific community is today both institutionalized and many-faceted based both on dominant perspectives, often emanating from positivist accounts, and, during recent decades, expanded qualitative approaches for doing scientific research. This has provided broadened and varied views on research quality in qualitative research (Denzin \& Lincoln, 2011), partly also opening up the quality research arena for participatory and action research approaches (Guba \& Lincoln, 1989; Lincoln \& Guba, 1985; Merriam \& Tisdell, 2016). In this wider variety of research approaches and understanding of science, conceptions of quality are in flux. Furthermore, the quality discourse does not yet fully recognize and incorporate the special characteristics and purposes in participatory and action research approaches and tradition. In this varied community and loose tradition, "action research" is a main appellation used (Bradbury-Huang, 2015; Reason \& Bradbury, 2001a, 2008); other more or less frequent connotations are "participatory action research" (Fals-Borda, 1979; Fals-Borda \& Rahman, 1991; Whyte, 1991), "participatory research" (Brown \& Tandon, 1983; Hall et al, 1982), "interactive research" (Nielsen \& Svensson, 2006; Svensson et al., 2007), "collaborative inquiry/research" (Heron, 1996), and "engaged scholarship" (Van de Ven, 2007). A core impetus of this intersecting variety of research approaches is making science relevant and useful for solving pressing problems and improving social conditions. An equally important impetus is enabling stakeholders to participate in research and development processes. It points to two basic norms in organizing and managing research that can capture defining characteristics: a focus on action and practice and a focus on interaction, participation, and collaboration. Active and interactive research roles and relations in scientific inquiry are distinguishing design parameters compared to mainstream science, where passive and distant positions are generally the norm.

There are opportunities for doing better, higher-quality research combining rigour and relevance that are not fully recognized and focused on (Greenwood, 2002; Gustavsen, 1992). However, quality in this type of research is unclear and has different meanings (Checkland \& Howell, 1998; Coghlan \& Shani, 2014; Eikeland, 2006, 2008, 2012; Feldman, 2007; MacIntosh \& Bonnet, 2007; Martí \& Villasante, 2009; Susman \& Evered, 1978). There is also a view that scientific excellence tends to be compromised, at risk, or of lower scientific standards in participatory and action research (Bradbury-
Huang, 2010; Bryman, 2016; Levin, 2012). The purpose of this article is to develop an argumentation on how quality in participatory and action research can be interpreted with a special focus on how to understand and thus redefine central concepts such as validity, reliability, and objectivity. I will, in this first of two articles, develop quality frameworks for participatory and action research based on a broader set of purpose in science and a wider understanding of validity and validation. Reliability and objectivity in participatory and action research will be the focus of a subsequent article (Lindhult, 2019).

It should be noted that these quality concepts are contested and are sometimes rejected both in the qualitative research domain as well as in participatory and action research. This motivates proposals of alternative concepts of quality in the search for more adequate understanding of what is excellent in participatory and action research. In finding its own identity, a more separatist approach is recognizable, pointing to dimensions different from other approaches and requiring its own qualities and standards (Bradbury \& Reason, 2001; Reason \& Bradbury, 2001b). For example, Peter Reason, a leading researcher in the debate on the quality of action research and the search for its identity, points to four such characteristic dimensions: 1) worthwhile practical purposes, 2) democracy and participation, 3) many ways of knowing, and 4) emergent developmental forms. These represent "a broad range of criteria beyond those of the empirical research paradigm" (Reason, 2006). In addition to Reason (2006), to my mind, one of the most elaborate attempts is made by Herr and Anderson (2015; but there are others, e.g., Coghlan \& Shani, 2014), who point out that their notion of quality "departs radically from those of both quantitative and qualitative research". But they want to retain the language of validity for strictly strategic reasons. Objectivity and reliability are not part of this strategic move (I will deal with these concepts in the subsequent article). Although they do not intend to "speak with an authoritative academic voice" about research quality for participatory and action research, they still want to provide an authoritative voice for successfully completing dissertations, that is, works that have to be accepted in academia, legitimized in this traditional institution for science. Thus, academic legitimation is their strategic goal in entering the traditional battlefield of scientific quality by formulating alternative qualities for participatory and action research (e.g., democracy) in the cloak of validity: dialogic validity, outcome validity, catalytic validity, democratic validity, and process validity. They are offering these criteria in the hope being "widely 


\section{Scientific Excellence in Participatory and Action Research: Part I. Rethinking Research Quality Erik Lindhult}

cited and summarized in mainstream research texts (...) may provide the legitimation needed to get a dissertation through a less than totally sympathetic dissertation committee" (Herr \& Anderson, 2015). To what extent this tactic will succeed is still open; Herr and Andersson (2015) see their offering of validity criteria as "tentative and in flux". This might seem daunting for people attracted to use participatory and action research approaches, but the situation of quality conceptions in flux also goes for the whole quality research field with the use of the traditional concepts as contested (Denzin \& Lincoln, 2011; Leung, 2015; Merriam \& Tisdell, 2016).

I agree that the institutionalization tactic propagated by Herr and Anderson (2015) is a fair point and that it might work well in the long run. My integrational aim is instead based on a stronger claim: to speak in an authoritative scientific voice in the sense of providing convincing arguments for more fruitful conceptualization of validity, objectivity, and reliability that can provide good support and space for participatory and action research and having persuasive force in the ongoing academic debate on research quality. This reconstruction is required to develop the status of participatory and action research as a not only acceptable, but also fully recognized and respected, family members in the community of scientific approaches in the academic community - and society at large.

\section{Reconstructing understanding of scientific inquiry and traditional quality concepts}

In order to clarify scientific excellence in participatory and action research, I will pinpoint epistemologically favourable dimensions that participatory and action research approaches to inquiry can realize in effective, high-quality research practices. It is a contribution to clarify the ability of participatory and action research "to deal with the traditional tasks of research in a way which is superior to other schools of thought" (Gustavsen, 1992). It builds on advancement in understanding of the epistemological significance of action and praxis pointing to an extended and pluralist epistemology (Heron, 1996). This requires rethinking of the philosophy and practice of science, and this rethinking often finds support in different dimensions of pragmatic- or practice-inspired philosophy (i.e., Dewey, 1939; Habermas, 1971, 1984, 1987; Rorty, 1979; Schön, 1983; Santos, 2014; Wittgenstein, 1984; Foucault, 1980). I will here clarify the relation between science, inquiry, knowledge, and truth with the aid of John Dewey, particularly his emergent crystallization of his theory of inquiry in his later years (Dewey, 1929, 1939).
Dewey is criticizing the spectator orientation and the subjectivism of established epistemology, where knowledge and the conceptions of truth are based on the metaphor of mental mirroring of objects in a given, external reality (Dewey, 1929; Rorty, 1979, 1998). Dewey argues that the development of knowledge cannot be done purely mentally, just inside one's head. "Men have to do something to the things when they wish to find out something; they have to alter conditions" (Dewey, 1929). "A known object exists as the consequences of directed operations, not because of conformity of thought or observation with something antecedent" (Dewey, 1929). When we are able to drive a car, ride a horse, get a new product to work in a stable way, that is, secure intended and valued consequences projected as possibilities by our ideas that direct our action, we possess knowledge, we show intelligence. Knowledge is not in this view accurate conceptual mirroring of a given reality, but instead it is of a reality constructed and harnessed to human ends. That is, data, ideas, propositions, and laws are means of knowing, not its objects (Dewey, 1929).

This points to an actor- and praxis-oriented view where knowledge is the capacity to act to transform conditions to accomplish human aims and goods. Table 1 depicts core dimensions in a spectator-oriented and praxis-oriented epistemologies and points to opportunities for research quality in a praxis orientation to knowledge and scientific inquiry.

Participatory and action research may be backed by a spectator orientation to knowledge, for example, as enabling field experiments as the first generation of action research used in its scientific legitimation. Overall, it does not, in this orientation, receive much epistemological support but rather is perceived as disturbing the research object through more active and collaborative roles and relations. The scientific qualities, according to the standard use of mainstream quality concepts, tend to disfavour participatory and action research: validity as the extent to which models, theories, or concepts correspond to features of reality; reliability as consistency in measuring different dimensions (i.e., mirroring) of research objects; and objectivity as avoiding any "subjective" intrusion. Furthermore, participatory and action research is, from a spectator view, seen as "activist" in bringing in non-scientific values of human needs, utility, participation, and democracy into the understanding of science.

First, participatory and action research comes more into its own in a movement from a spectator orientation 


\section{Scientific Excellence in Participatory and Action Research: Part I. Rethinking Research Quality Erik Lindhult}

Table 1. Spectator- and praxis-based epistemological orientations

\begin{tabular}{|c|c|c|c|}
\hline & Spectator Orientation & Praxis Orientation & $\begin{array}{l}\text { Research Quality Potential in } \\
\text { Praxis-Oriented Approaches }\end{array}$ \\
\hline $\begin{array}{l}\text { Character of } \\
\text { knowledge }\end{array}$ & $\begin{array}{l}\text { Faithful depiction of given } \\
\text { reality (truth as } \\
\text { correspondence) }\end{array}$ & $\begin{array}{l}\text { Competent reconstruction of } \\
\text { situations to realize human } \\
\text { goods }\end{array}$ & $\begin{array}{l}\text { Trustworthiness in achieving } \\
\text { human ends }\end{array}$ \\
\hline $\begin{array}{l}\text { Human interests } \\
\text { and purpose }\end{array}$ & $\begin{array}{l}\text { Basic research ideally free from } \\
\text { interests (other than advancing } \\
\text { knowledge and individual } \\
\text { curiosity) }\end{array}$ & $\begin{array}{l}\text { Inherent in } \\
\text { knowledge/knowing as a } \\
\text { competent activity }\end{array}$ & $\begin{array}{l}\text { Purposive, trustworthy } \\
\text { resolution of concerns, praxis } \\
\text { improvements, and } \\
\text { transformations }\end{array}$ \\
\hline \multirow{2}{*}{$\begin{array}{l}\text { Relation to } \\
\text { stakeholders / those } \\
\text { affected }\end{array}$} & Research on... & Research with... & \multirow{2}{*}{$\begin{array}{l}\text { Mobilize and pool distributed } \\
\text { forms of knowledge and } \\
\text { research capacity }\end{array}$} \\
\hline & $\begin{array}{l}\text { Subjects as study objects / data } \\
\text { source ("respondents") }\end{array}$ & $\begin{array}{l}\text { Subjects as participants in } \\
\text { research }\end{array}$ & \\
\hline \multirow{2}{*}{$\begin{array}{l}\text { Position of } \\
\text { research }(\text { ers })\end{array}$} & Detached, passive & Engaged, (inter)active & \multirow{2}{*}{$\begin{array}{l}\text { Situated, mutual learning } \\
\text { processes among participants in } \\
\text { different roles }\end{array}$} \\
\hline & Ideally outside research context & $\begin{array}{l}\text { Researchers can have various } \\
\text { positions and roles }\end{array}$ & \\
\hline $\begin{array}{l}\text { Knowledge } \\
\text { development about } \\
\text { research object }\end{array}$ & $\begin{array}{l}\text { Depicting knowledge objects as } \\
\text { they "are" }\end{array}$ & $\begin{array}{l}\text { Constructing / creating } \\
\text { research objects }\end{array}$ & $\begin{array}{l}\text { Trustworthy design of new or } \\
\text { improved objects to enhance } \\
\text { human value }\end{array}$ \\
\hline
\end{tabular}

to a praxis orientation toward knowledge and scientific inquiry. The character of knowledge is a less faithful depiction of a given reality (truth as correspondence) instead of a competent reconstruction of situations to realize human goods. Knowledge is an outcome of competent and controlled inquiry, of intelligence: "Were we to define science not in the usual technical way, but as a knowledge that accrues when methods are employed which deal competently with problems that present themselves, the physician, engineer, artist, craftsman, lay claim to scientific knowing" (Dewey, 1929). The potential for research quality is not in mirroring reality but in warranting and enhancing the trustworthiness of achieving human ends. Like with a global positioning system (GPS) in an automobile, which extends the driver's sense of direction as a form of knowledge, the point is not to mirror reality exactly. The precision of a GPS is normally not more than in the range of 10 to 100 metres, but this is sufficient for the purpose (when combined with the driver's training and recognition of road signs and landmarks) and has satisfactory trustworthiness. The insights and tacit skills of the situated actors is combined with the embedded rule-based expertise of the GPS equipment in warranting judgments in ongoing inquiry and future action.
Second, in a spectator orientation, knowledge and inquiry are ideally free from the interference of human interests, which can compromise research quality, a core quality of "basic" research. In a praxis orientation, purposes and ends in trustworthy resolution of concerns and problems, praxis improvements, and transformations are inherent in knowledge and inquiry as competent activity. It calls for consideration of a wider spectrum of purposes as inherent in different forms of scientific inquiry. As Dewey says, "If the living, experiencing being is an intimate participant in the activities of the world to which it belongs, then knowledge is a mode of participation, valuable in the degree in which it is effective. It cannot be the idle view of an unconcerned spectator... knowing has to do with reorganizing activity, instead of being something isolated from all activity, complete in its own account." (Dewey, 1946). For example, by extending your knowing through using a GPS, you reorganize your modes of transportation (incorporating consulting the GPS system to enhance your sense of orientation), making it more effective in achieving new and enhanced ends.

Third, in relation to stakeholders and others affected, that is actors in and in relation to the context of the 


\section{Scientific Excellence in Participatory and Action Research: Part I. Rethinking Research Quality Erik Lindhult}

problem domain receive enhanced status beyond being study objects and data sources ("respondents"). Instead of research on subjects, a praxis orientation in science shifts more to research with subjects as participants in research. It calls for an extended epistemology where the knowledgeability of actors is coming into focus and the way it can enhance scientific excellence by mobilizing and pooling distributed forms of knowledge and research capacity. Fourth, the position of research and researchers in a spectator orientation is detached and passive, ideally outside research context in order to avoid any epistemologically compromising interaction. In a praxis orientation, the inquirer is not standing outside the problematic situation like a spectator. They are engaged in it and in transaction with it. Researchers can have various positions and roles. They can be a researcher with a particular responsibility for high-quality inquiry but also as physician, engineer, artist, or craftsman, as Dewey is saying. The epistemologically transformed relation to actors in and related to the research context and the situated positionality of the inquirers opens up opportunities for scientific excellence through situated, mutual learning and inquiry processes among participants in different roles in co-producing knowledge. Here, open communication on equal terms among participants is a way to unleash different forms of knowing and inquiry and avoid dominance of a particular understanding of knowledge and knowledge interests (Gustavsen,1986; Habermas, 1984, 1987; Kemmis, 2008; Santos, 2014). It points to participatory and discursive democracy as a philosophical and practical point of departure for scientific, high-quality inquiry (Gustavsen, 1992, 2017; Lindhult, 2015).

Fifth, if we look around us, we see that reality is to a large extent shaped and crafted by people through inquiry and knowledge creation, such as communication and transportation praxes and systems. Thus, knowledge development about research objects cannot just be depicting knowledge objects as they "are". Through scientific inquiry, research objects, such as cars, GPS systems, the Internet, and social innovations such as sharing and caring systems, are to a large extent created. Thus, there are opportunities for scientific excellence in trustworthy design and innovation of new or improved objects to enhance human value and achieve new projected ends. As Kurt Lewin said, indicating a wider view of research quality, "creating, not predicting, is the most robust test of validity-actionability" (Kaplan, 1998).

Generally, a praxis-oriented relation to inquiry urges us to move from a contemplative and spectator orientation towards a creative and participatory orientation to inquiry (Reason, 2006; Reason \& Bradbury, 2001a). Instead of the traditional conceptualization of truth as correspondence, it is appropriate to use trustworthiness to indicate a plural, fallibilistic, and praxis-oriented view of knowledge. It is the degree to which claims or constructions are worthy of our trust that forms a basis for further inquiry and action. Validity, reliability, and objectivity are different qualities of trustworthiness of claims to knowledge. I will show how these quality notions in mainstream research methodology are also fruitful in participatory and action research. In line with the purpose, this first article thus addresses a wider spectrum of purposes and interests for the understanding of research quality in scientific inquiry, as well a wider variety of truth-developing and justification practices that can warrant trustworthiness of assertions and proposed actions.

\section{Worthwhile Purposes in Science}

What is science for? Beyond doubt, science has created considerable benefits for people, organizations, and communities. The questioning of received learning and spaces for open, systematic searches for its advancement is fundamental in scientific activity (Alvesson \& Sandberg, 2013). However, the purpose beyond advancing scientific funds of knowledge is often seen as an extra-scientific concern, something entering in secondary phases when scientific knowledge is to be applied for improving practice and generating innovation. But, purposes and aims can be seen as a constitutive feature of what is defined as good research. A point of action and participatory research is that the purpose of scientific activity is more than curiosity and more than basic research, traditionally seen as research free from any consideration of purposes and interests. One distinguishing feature of action research is the focus on production of knowledge for worthwhile human purposes. Not only is trustworthiness part of research quality but so is "purpose-worthiness". Thus, basic research is rather basic in the sense of focusing on the fundamental needs and challenges of people, organizations, and societies. Collaborative and participatory research, as a consequence of being collaboration between different stakeholders with various knowledge interests, need to consider purposes beyond academic interests in advancing knowledge in particular disciplines of science. As Habermas (1971) points out, knowledge is constituted by human interests in managing and controlling conditions, in understanding, communication, and concertation in social situations, and in empowerment and emancipation from unnecessary powers and hardships. 


\section{Scientific Excellence in Participatory and Action Research: Part I. Rethinking Research Quality Erik Lindhult}

The broadening of the framework for quality can be connected to Habermas' widened conceptualization of truth, implying that knowledge claims are made and redeemed in a broader range of dimensions, not only truth as correspondence with reality, but also efficiency/utility, normative rightness, and authenticity/truthfulness (Habermas, 1984, 1987).

Engagement and purpose have deeper groundings that are also integrated in science. Ontologically, we human beings are always already situated and engaged, or projected, as Heidegger (1962) says, in the world, constituted by needs as well as and challenges, dangers, and opportunities experienced and imaginatively envisioned. Epistemologically, knowledge is something that accrues and can be claimed to the extent that problems and problematic situations can be dealt with competently and, thus, worthwhile purposes can be trustworthily approached and situations can be improved (Dewey, 1939). Participatory and action research is to an important extent, integrating elements of science of design (Simon, 1996) and professional practice (Schön, 1983), where ideation and experimentation to construct new, artificial objects to achieve goals are core dimensions in inquiry. Goals seeking is also an integral part.

\section{A Wider Spectrum of Aims and Qualities}

There are different dimensions of quality depending on the main character of aims focused on in inquiry efforts, as shown in Table 2. I argue that participatory and action research often wavers between different types of aims. The discussions of "purpose worthiness" tend to be lacking in elaboration in participatory and action research, according to Bradbury and Reason (2001). Often, some type of aim is emphasized while other aims are downplayed or neglected. This may be acceptable as long as it is made in a conscious way that is appropriate to the project and circumstances at hand. It is also often difficult to distinguish between different aims in practice, but I stress the importance of maintaining the distinctions in order to make appropriate quality judgments. For example, participatory and action research, coming out of a context where more radical social transformation is called for in order to improve the situation of underprivileged groups (e.g., the southern tradition, see Brown \& Tandon, 1983), generally has a stronger emphasis on normative-political aims. An important emphasis is that people should do their own research in order to democratize knowledge production and as part of their self-liberation. On the other hand, academic research aims tend to be placed in the background where it often seems to be enough that the knowledge that people produce is judged to be useful by the people themselves in their struggle for liberation. While this is an important and neglected dimension of scientific/research quality that participatory and action research quite rightly is emphasizing, there are also other quality dimensions of this aim.

Table 2 indicates and exemplifies the way quality understanding, as well as the role of action, practice, and practitioners, is shifting depending of areas of purpose in knowledge production. High-quality, scientific knowledge can be developed in scientific inquiry aimed at realization of different purposes, but quality is perceived differently. The academic type of purposefulness is familiar, referring to advancement of knowledge in a field of study, which in the dominant linear model is autonomous basic research going further to application and innovation in society. Where there is integration in this process, it is clearly beneficial for society, but there are also critics. Alvesson, Gabriel, and Paulsen (2017) argue that there has been decline in the quality of social science research, with a proliferation of meaningless research of no value to society. The assumption is that academics are doing research in order to get published, not to say something socially meaningful. This view leads to the rise of nonsense in academic research, which represents a serious social problem leading to extensive waste of resources and costs to tax payers. This indicates that participatory and action research, with a focus on worthwhile purposes, has a role in restoring meaning and value in social science by integrating academic research with human development. Alvesson, Gabriel, and Paulsen's (2017) analysis particularly focus on the less worthwhile personal purpose in prevailing system of knowledge production, something that also requires structural transformation related to the normative-political domain in order to enhance social value created in the system.

In the practical domain, actual change for solving problems and improving conditions is crucial for scientific quality in realizing value, and workable, robust solutions. Often, practitioners have important roles in creating, testing, and assessing knowledge claims embedded in new practices and methods. In this domain, usefulness and efficiency of solutions are focused on, that is, what Weber (1978) calls rationality in relation to given value frameworks (zweckrationalität). In the normativepolitical domain, the domain of Weberian value rationality (wertrationalität), frameworks for valuation and structures of power are also questioned. Quality and knowledge generation are, in this domain, focused on the extent to which these frameworks and structures 


\section{Scientific Excellence in Participatory and Action Research: Part I. Rethinking Research Quality Erik Lindhult}

Table 2. Purpose domains and quality dimensions in participatory and action research

\begin{tabular}{|c|c|c|c|c|}
\hline \multirow[b]{2}{*}{ Dimensions } & \multicolumn{4}{|c|}{ Area of Purpose } \\
\hline & Academic & Practical & Normative-political & Personal \\
\hline $\begin{array}{l}\text { Orientation to } \\
\text { participatory } \\
\text { and action } \\
\text { research with a } \\
\text { focus on } \\
\text { different aims }\end{array}$ & $\begin{array}{l}\text { Focus of non-action- } \\
\text { oriented research, also } \\
\text { part of most } \\
\text { participatory and } \\
\text { action research } \\
\text { orientations }\end{array}$ & $\begin{array}{l}\text { Pragmatic-oriented } \\
\text { participatory and action } \\
\text { research, Scandinavian } \\
\text { action research, } \\
\text { positivist or action } \\
\text { research, e.g., } \\
\text { Lewin/organization } \\
\text { development tradition }\end{array}$ & $\begin{array}{l}\text { Critically oriented action } \\
\text { research (also partly } \\
\text { postmodernist and } \\
\text { constructionist or action } \\
\text { research), mainly } \\
\text { participatory action } \\
\text { research (Freire, Fals- } \\
\text { Borda) }\end{array}$ & $\begin{array}{l}\text { Life-oriented action } \\
\text { research, practitioner- } \\
\text { oriented action research, } \\
\text { human inquiry (Reason) }\end{array}$ \\
\hline $\begin{array}{l}\text { Value } \\
\text { (relevance) }\end{array}$ & $\begin{array}{l}\text { Advancement of } \\
\text { knowledge in a field of } \\
\text { study, application of } \\
\text { findings, dissemination }\end{array}$ & $\begin{array}{l}\text { Innovation of product / } \\
\text { process, new } \\
\text { understanding, new } \\
\text { alternatives, self- } \\
\text { development }\end{array}$ & $\begin{array}{l}\text { Democratization, } \\
\text { liberation, social or } \\
\text { wealth development, } \\
\text { justice, support of } \\
\text { political process, } \\
\text { rationalization }\end{array}$ & $\begin{array}{l}\text { Personal / life } \\
\text { development, } \\
\text { professional } \\
\text { development, personal } \\
\text { value/moral } \\
\text { development }\end{array}$ \\
\hline Validity & $\begin{array}{l}\text { Valid theories, data, } \\
\text { knowledge claims }\end{array}$ & $\begin{array}{l}\text { Workable, efficient } \\
\text { solutions and praxis }\end{array}$ & $\begin{array}{l}\text { Moral-political } \\
\text { transformation } \\
\text { (rationalization) }\end{array}$ & $\begin{array}{l}\text { Authenticity, good life } \\
\text { for individuals and those } \\
\text { concerned, and one's } \\
\text { community }\end{array}$ \\
\hline Reliability & $\begin{array}{l}\text { Reproducible and } \\
\text { accountable research } \\
\text { process }\end{array}$ & $\begin{array}{l}\text { Robust solution, stable } \\
\text { praxis }\end{array}$ & $\begin{array}{l}\text { Sustainability of } \\
\text { transformation }\end{array}$ & $\begin{array}{l}\text { Skill and personal } \\
\text { excellence, security, } \\
\text { limited risks involved, } \\
\text { enabling context }\end{array}$ \\
\hline $\begin{array}{l}\text { Role of action } \\
\text { and practice }\end{array}$ & $\begin{array}{l}\text { Application and quality } \\
\text { test of knowledge } \\
\text { claims }\end{array}$ & $\begin{array}{l}\text { Instrumental for change, } \\
\text { experimentation, } \\
\text { development and } \\
\text { validation change } \\
\text { hypotheses, } \\
\text { implementation and } \\
\text { dissemination of } \\
\text { solutions }\end{array}$ & $\begin{array}{l}\text { Ethical-political struggle } \\
\text { for improvement of } \\
\text { human conditions, } \\
\text { development and } \\
\text { validation of } \\
\text { transformative } \\
\text { hypotheses }\end{array}$ & $\begin{array}{l}\text { Self-reflection, self- } \\
\text { realization, identity } \\
\text { formation; first-person } \\
\text { inquiry }\end{array}$ \\
\hline $\begin{array}{l}\text { Role of } \\
\text { practitioners }\end{array}$ & $\begin{array}{l}\text { Data sources for } \\
\text { inquiry, respondent / } \\
\text { use validation }\end{array}$ & $\begin{array}{l}\text { Innovators, change } \\
\text { agents, participants in } \\
\text { inquiry, users, } \\
\text { beneficiaries }\end{array}$ & $\begin{array}{l}\text { Subjects and actors of } \\
\text { struggle for } \\
\text { emancipation and } \\
\text { realizing values / ideals }\end{array}$ & $\begin{array}{l}\text { Partners in self- } \\
\text { development and co- } \\
\text { inquiry }\end{array}$ \\
\hline
\end{tabular}

can be questioned and influenced and the extent to which alternatives can be envisioned and generated, and can sustainably transform conditions. There are many areas and contexts where dominant value frameworks and related power structures need to be questioned and challenged as part of and enabled by processes of scientific knowledge production, from recognition of and satisfying needs of marginalized groups to valuation and power shifts in today's digital transformation of industry and society in order to achieve sustainable communities and a sustainable planet. Here, the role of action, practice, and practitioners in knowledge generation is crucial to knowledge generation in many ways, for example, by acting differently to expose and challenge ingrained norms and power structures and by forming alliances that can test 


\section{Scientific Excellence in Participatory and Action Research: Part I. Rethinking Research Quality Erik Lindhult}

transformative hypotheses and effect change. As Dewey (1939) says, in social inquiry, behavioural changes and participation of the concerned are inherent in enacting and testing claims to knowledge beyond describing existing conditions.

Personal value is rarely mentioned as central in the research community, but, as I see it, it is most central to and is even a prerequisite for the other value dimensions (Marshall, 2016; Reason, 2006). The subjective is a necessary starting point for any research. It is recognized as an important research "instrument" in interpretative-oriented research. The "I" of science, the actor in research, is an important ingredient in any research activity (Brown, 1996) and its capacity for excellence. If knowledge is to be developed, someone, often several people in collaboration, have to learn something new and significant. Based on this dimension, value creation is linked to what Reason and Bradbury (2001b) call "the flourishing of individual persons and their communities". Validity gains meaning from authenticity, in other words, learning and development that the individual feels "at home" in, recognizes, and can identify with in relation to values and ideals. Reliability is the meaning of security - security and health in development - with limited personal risks. The action dimension based on personal value for the involved can involve competence and career development, self-reflection, self-realization, and identity formation. Practitioners' importance and role gain the character of equal partners in development and learning, where the priority of what is considered valuable development and learning often varies between those involved.

A similar differentiation of aims of inquiry often referred to is the distinction made between "for me" (the personal value and development), "for us" (the people wanting praxis improvement), and "for them" (those outside the context of change, requiring consideration of the wider significance of achievements) (Reason \& Torbert, 2001). In addition, there is a broader politicalethical definition of aims including such values as freedom, democracy, and justice, for example, "us" as part of a group aiming to improve the underprivileged status of certain groups such as workers, impoverished people, and people with disabilities based on values institutionalized in the community at large. A basic point of participatory and action research is that quality can be achieved from the point of view of different types of aims and thus a broader range of interested parties in a mutually beneficial way.
The ideal is that these different interests can be furthered by the same activities (Clark, 1976), for example, experimentation that is enabling creativity and learning, generation of new knowledge (e.g., concerning an understanding of a problem or a transformative hypothesis), and forceful action for resolution of problems and transforming situations. In each context or project, the combination of purpose must also integrate interests of parties and stakeholders to a sufficient degree so that a common ground can be established based on mutual agreement and shared understanding. Note that good inquiry management is needed to achieve such mutually beneficial aims in a workable and efficient way. Aims and purposes do not combine harmoniously and automatically; it requires organization and management by those responsible for participatory and action research initiatives. This is a basic challenge in managing participatory and action research so as to empower different parties, to critically reflect on existing power relations and their implications and possible transformation, and to build collaborative power among stakeholder for common participatory and action research enterprises and ventures (Gaventa \& Cornwall, 2008; Hafting \& Lindhult, 2013).

\section{Rethinking Validity}

Creating trustworthiness is a pluralistic enterprise and so is validity. Validity means reaching sound and grounded claims to knowledge. Traditionally, this has been the domain of conceptions and practices of truth. I will draw on different perspectives on and theories of truth to identify different approaches to validation of knowledge, which can also be seen as different designs of inquiry systems (Churchman, 1971). These perspectives are also used in everyday assessment of knowing in practice, such as sensing, testing, consulting with others or with texts, discussing, integrating pictures of evidence, and debating people with different views (Lindhult, 2008). The different perspectives are also related to different forms of knowledge (e.g., practical and theoretical, tacit and explicit, physical and cultural) and procedures of inquiry. Quality, as well as the understanding of action and participation in inquiry, is also dependent on orientations to inquiry, for example, positivist, interpretative, critical, constructivist, pragmatic (Johansson \& Lindhult, 2008; Lindhult, 2002). The quality dimensions achieve different emphasis and conceptualization depending on dominant orientation. For example, a good representation (positivist orientation) is able to match propositions with data about reality (correspondence view of validity), a good interpretation 


\section{Scientific Excellence in Participatory and Action Research: Part I. Rethinking Research Quality Erik Lindhult}

(interpretative orientation such as hermeneutics) is able to integrate different meaning making elements into a whole (coherence view of validity), while a good critical hypothesis (critical orientation) is able to unmask coercive power relations and can be vindicated through discourse free from distorting power influences (discursive view of validity). Participatory and action research provides particular opportunities for validation compared to other approaches to inquiry. At the same time, participatory and action research also has its particular validity weaknesses and risks. A core issue of inquiry management is to exploit these opportunities and, at the same time, minimize weaknesses. As an orientation for inquiry management and judgment of quality, Table 2 gives an overview of different dimensions of validation and its relation to participatory and action research.

\section{Correspondence validation}

Correspondence validation is the dominant conception of truth and validity in science. It is a process where ideas about research objects are matched to empirical material, action, and experience. It is an interaction between guiding assumptions and research constructs, its operationalization in concrete research activities, and its extended networks of directly experienced and interpreted implications and consequences. Construct validity is used to assess the extent to which concepts and models (i.e., constructs) can faithfully depict objects of knowledge and their characteristics. Internal validity is evidenced by patterns of dynamics and causal relations in the area of study while external validity is evidenced by patterns that can be inferred to similar areas and contexts or more generally. These forms of validation can also be dealt with through the other validation procedures described in Table 2.

The assumption of generality of knowledge assessed in external validation is often played down in qualitative research as well as in participatory and action research (Coghlan, 2016). The assumption of generality, inspired by ideals from natural science, as not only a quality of knowledge but a standard of knowledge, tends to downgrade social and cultural knowledge to an imperfect and "anecdotal" status. It is already mentioned by Bacon (1960), a founder of modern science, as type of idol, an illusion of the mind, in adhering to false analogies and assuming greater order and regularity in the world than is actually the case. Still the wider import and validity of knowledge is an important quality dimension. Greenwood and Levin (2006) are tuning down external validity to "transcontextual credibility": the way knowledge can have validity in different contexts. Parti- cipatory and action research provides opportunities for access to measurement/testing possibilities, where matching concepts and objects of knowledge can be developed and more grounded conceptualization can lead to increased construct validity. Internal validation can be increased by mobilizing a broader range of knowledgeable individuals. In the domain of some design sciences, such as various engineering and professional disciplines, external validation can be rather high (e.g., medical treatment) or product development (e.g., think of the rather broad validation in the uses of mobile communication systems). But evidence from action research shows that pure copying as a mechanism for generalization seldom works. It assumes that knowledge structures could be successfully standardized and "frozen" in practices, methods, and tools with a degree of context independence or robustness. But, external knowledge elements often tend to be used in combinatorial, associational, and inspirational ways in developing contextual solutions appropriate for each situation, such as in a new organization of work suitable for a particular workplace. Furthermore, participation in the creation of sustainable, local solutions among those concerned is often required to mobilize local knowledge and build necessary commitment (Gustavsen, 1992).

Lincoln and Guba (1985) reconceptualize external validation as transferability. This shifts the responsibility for validation from the developer of knowledge more to the user of it in others' situations and contexts. A precondition is that the researchers have documented the knowledge to a sufficient degree (i.e., they have a sufficiently "thick" description) so that other users are able to understand and integrate it in their own inquiry. What is more general might be the generative mechanisms used (e.g., procedures of inquiry, dialogic procedures) to create solutions to problematic situations rather than generality of certain knowledge elements in particular solutions. The attractiveness of a correspondence view is partly conditioned on the dominant spectator and visual metaphor of knowledge focused on correct mirroring of a given reality. Then, active and collaborative research roles tend to be seen as irrelevant to or at risk of disturbing and corrupting the "true" relation of concepts and mental models on the one hand and data about objects given in reality on the other. With a more pragmatic and praxis orientation to science, correspondence is more something created by competent inquiry in the relation secured between ideas and their consequences. Then other dimensions of validation described below are put in play, giving more credibility and greater leeway for participatory and action research to enact scientific validation. 


\section{Scientific Excellence in Participatory and Action Research: Part I. Rethinking Research Quality Erik Lindhult}

\section{Coherence validation}

Coherence validation focuses on how different empirical, interpretative, and conceptual elements can be integrated and thus mutually reinforce one another in a meaningful and reasonable whole, such as a theory or conceptual framework. This is the main validity dimension in interpretative research in developing interpretations that can function as meaning nexus in understanding (see, e.g., Dilthey, 1979), which is also evident in methods of triangulation of various data sources or assessments, for example, in case research, and in systemic explanations. Participatory and action research provide opportunities for considerable richness and variety of experience/data and meaning relations as well as can take advantage of interpretative capacities of stakeholders, but may also lead to overburden by richness of experience and meaning, and to fragmentation rather than validation. On the other hand, objects of knowledge do not only display harmonious unity but also differences, anomalies, tensions, and conflicts, which can point to additional and deeper understanding of a plural reality and a more critical perspective on coherence validation, for example, in reflexive interpretative work (Alvesson \& Sköldberg, 2018).

\section{Discursive validation}

Discursive validation is a significant opportunity and aim in collaborative and participatory research approaches in mobilizing different expertise and forms of knowing of a broader range of people. This is in line with emphasizing dialogic and democratic validity in participatory and action research (Herr \& Anderson, 2015; Reason, 2006). Discursive validation as a procedure also occurs in the research methodological literature, for example, in the form of feedback of printed interviews (e.g., in respondent validation or "member checks"). The starting point is then often that the researcher has produced some text or material that the practitioners are invited to react to and comment on, and thus validate. The ideal within participatory and action research is also that researchers and practitioners together can make experiences, generate data, analyze and produce conclusions, or even that practitioners themselves do research about their reality (often called practitioner research), often with the support of experienced researchers. Discursive validation is something that can be continuous in the interaction and affect different phases and parts of the work, and thus affect the outcomes of inquiry. Practitioners can reflect on and give views on experiences and events in the inquiry process. It is important that there are good forums in the collaborative processes where validating dialogue can be carried out. There is often a need for continuous work to build such forums in the form of open, democratic dialogue and exchange between participants. Here, one can see the research role as a "publican role", an audience- or public-supportive role that aims to open up communicative spaces (Kemmis, 2008) and create a basis for dialogue on equal terms between different parties involved (Gustavsen, 1992; Lindhult, 2005; Pålshaugen, 2002). It means organizing interactive and collaborative learning processes generating high-quality knowledge for all participants. A dominance-free communication in the spirit of Habermas (1984) between competent and concerned persons, who, through discussion, strive for coordinated understanding and practical agreements. This relates to the idea of open, public, critical conversation between equal citizens as a way of sifting out "truth" and utilizing common intelligence to find solutions to societal problems.

Wider discursive validation is a central ambition within participatory and action research. It clearly provides additional opportunities for validation but also leads to a number of difficult issues in itself. The researcher may be given a privileged expert role and is considered by their academic affiliation to have a better knowledge or analytical ability. It creates trusting relationships that can make it more difficult to openly and critically discuss different issues (Svensson et al., 2007). The discourse and language use of the research community, as well as the interests of knowledge, can be widely different from the practice's discourse and language use, which leads to translation problems as well as negotiation rather than dialogue. What should be validated, who should participate, and how it can be carried out in a satisfactory way, are often not so easy to clarify. An agreement based on the combined expertise of actual participants may lack some important insight and learning. Time and motivation are often limiting factors for broader participation, there are often status differences and unequal recognition of expertise, as well as limited opportunities for different parties to familiarize themselves with issues relevant to the research. But, with all its limits, it is a procedure commonly used in the scientific community. The point in participatory and action research is to extend its uses to include additional parties in society.

\section{Practical validation}

Practical validation involves trying out ideas, approaches, theories, hypotheses, and solution proposals in practice and seeing how they "work" and create, or do not create, expected or novel effects (Dewey, 1939). This type of validation is included in the experimental focus of action research (Lewin, 1946), in the field experiment 


\section{Scientific Excellence in Participatory and Action Research: Part I. Rethinking Research Quality Erik Lindhult}

idea, as well as in experience-based learning (Schön, 1983). It is a common view on how action research is conducted and is incorporated in action research cycle models (Coghlan \& Brannick, 2014, McNiff et al., 1996; Stringer, 1999). Practical validation in live settings is a significant comparative advantage in action and participatory research, both in developing and testing knowledge claims and in realizing practical usefulness and transformation. To the extent that validation in real-life practice is necessary for particular knowledge claims to gain sufficient trustworthiness, all research needs to emulate aspects of action and participatory research - or else be based on less scientific everyday trial-and-error learning often seen as outside the domain of science. In line with a practical view on validation, Gustavsen (2014) emphasizes "participative constructivism" as a point of departure in validating "the ability of those concerned to themselves create and shape the society in which they live. It is these broadly framed movements that represent the primary generalization of action research knowledge, not textually expressed claims to generality, nor the specific measures applied to broaden and strengthen the movements." Thus, the shift and movement in practice is important in validation. As Dewey (1939) points out, in social inquiry (e.g., investigation of the validity of ways of organizing health care for rehabilitation of mental illness), it is not only agreement in discourse that is needed but also consonance in practices of organizing and practically validating the workability of models. To wait for some actors to try out new models is an option, but Dewey (1939), as well as Simon (1996), in developing a science of design, saw in the focus on experimentation also designing research situations where new models and artefacts are developed and tested and new experience systematically developed as important for valid scientific advance. It should be noted that general shifts in practice are indicators of practical validation based on inquiry and the learning of people involved, but are dependent on the standards of inquiry used. Both trustworthy claims and misconceptions can be diffused in practice depending on the degree to which inquiry is competent, that is, to what extent it lives up to scientific standards. In principle, the basic norms and practices for good knowledge creation and competent inquiry do not differ between scientific and everyday inquiry, only the degree to which they are used (i.e., situated problem and purpose formulation, development and test of suggestions for resolution, reasoned argumentation, systematic creation of evidence in experience, good use of available knowledge and inquiry capacity, consideration of alternative hypotheses for resolution, control of bias, openness for review and further inquiry, etc.) (Dewey, 1903/1976, 1939). Still, even the best inquiry can fail.

\section{Intuitive, dialectical, and perspectivist validation}

I see the four validation procedures described above as the most common in validating knowledge claims. To show a broader spectrum, I would like to mention three other validation approaches. Intuitive validation is based on knowledgeable persons who have a rich and extensive experience base from a particular activity, which provides the basis for a refined judgment in the domain of experience. A difficulty for outsiders is to examine the basis for an intuitive assessment. Track records of earlier judgments and how long the person has built up their knowledge base and judgment, as well as how close the area the person has worked are proxies. It is recognized in qualitative research in using length of time in the field interacting with and participating in research situation as indicator of validity. Articulation of the tacit knowledge base and the basis for the assessments through dialogue and reflection, so that these also become available and critically accessible by others (Nonaka, 1994; Schön, 1983), is also a "truth tactic".

The other two, dialectical and perspectivistic validation, both assume that reality is multifaceted. Dialectical validation means letting knowledge claims be confronted with their opposites in order to call in their possibilities and limitations and possibly achieve a synthesis of the opposites at a higher level. Hegelian logic is here a point of reference. Perspectivist validation is instead based on the assumption that it is the richness of perspectives that enables approaching a greater validity. Because several parties are involved in the research process, and that it is often closer to real situations with their openness to different interpretations and perspectives instead of assuming a predetermined theoretical view, such validation within participatory and action research is promoted. Both of these validation procedures increase the polyphony of various voices in the research, which is a general trend in participatory and action research. Such validation can be problematic in that it reveals ambiguities and conflicts that need to be addressed and can lead to a confusing cacophony of voices. At the same time, communicative openness is something that, on the basis of these dimensions of validation, is inevitable to approach a high-quality understanding of science.

Table 3 condenses the discussion on different validation dimensions. My hope is it can provide an overview of different validation opportunities and their relation to participatory and action research as a guide for organizing and managing research practices for validating different knowledge claims. 


\section{Scientific Excellence in Participatory and Action Research: Part I. Rethinking Research Quality Erik Lindhult}

Table 3. Validity dimensions and validation practices

\begin{tabular}{|c|c|c|c|}
\hline Validity Dimension & Measures & $\begin{array}{l}\text { Potential Advantage of } \\
\text { Participatory and Action Research }\end{array}$ & $\begin{array}{l}\text { Potential Weakness of } \\
\text { Participatory and Action Research }\end{array}$ \\
\hline Correspondence & $\begin{array}{l}\text { Construct development, } \\
\text { observation, measurement }\end{array}$ & $\begin{array}{l}\text { Measurement / testing } \\
\text { possibilities, grounded } \\
\text { conceptualization }\end{array}$ & Disturbing research domain \\
\hline Coherence & $\begin{array}{l}\text { Triangulation, } \\
\text { interpretation (unified } \\
\text { pattern), framing }\end{array}$ & $\begin{array}{l}\text { Richness and variety of experience } \\
\text { / data and meaning relations }\end{array}$ & $\begin{array}{l}\text { Overburdened by richness of } \\
\text { experience / meaning, } \\
\text { fragmentation }\end{array}$ \\
\hline Discursive & $\begin{array}{l}\text { Respondent validation, } \\
\text { member check, democratic } \\
\text { dialogue (communication } \\
\text { free of domination) }\end{array}$ & $\begin{array}{l}\text { Broader discursive validation } \\
\text { among concerned / competent } \\
\text { parties }\end{array}$ & $\begin{array}{l}\text { Arranging good forums difficult } \\
\text { (e.g., democratic, free of } \\
\text { domination, inclusive), dissensus }\end{array}$ \\
\hline $\begin{array}{l}\text { Practical } \\
\text { (workability) }\end{array}$ & Test by application / use & $\begin{array}{l}\text { Experimentation possibilities in } \\
\text { field / live context }\end{array}$ & $\begin{array}{l}\text { Limited control of and influence on } \\
\text { conditions }\end{array}$ \\
\hline Intuitive & $\begin{array}{l}\text { Judgment of experienced } \\
\text { person / expert }\end{array}$ & $\begin{array}{l}\text { Access to a broader spectrum of } \\
\text { experienced persons / expertise }\end{array}$ & $\begin{array}{l}\text { Difficult to examine intuitive } \\
\text { judgments }\end{array}$ \\
\hline Dialectic & $\begin{array}{l}\text { Comparative test of } \\
\text { competitive knowledge } \\
\text { claims }\end{array}$ & $\begin{array}{l}\text { Broader access to diverse views and } \\
\text { experiences }\end{array}$ & Polarization and conflict \\
\hline Perspectivistic & $\begin{array}{l}\text { Using plurality of } \\
\text { perspectives }\end{array}$ & $\begin{array}{l}\text { Multiple embodied perspectives } \\
\text { through participants, polyphony }\end{array}$ & $\begin{array}{l}\text { Cacophony, dominance of some } \\
\text { perspective }\end{array}$ \\
\hline
\end{tabular}

\section{Conclusion}

In this article, I have reconstructed the understanding of scientific excellence and research quality in participatory and action research in order to set out a clearer and more secure path for its scientific development. First, a reconstruction of understanding of scientific inquiry has been made based on a praxis-oriented epistemology inspired by pragmatism. Science is not only faithfully depicting existing objects of research but is, to a significant extent, creating them, which implies a movement towards "participatory constructivism" (Gustavsen, 2014). I have particularly focused on proposals of a wider role of purpose and a plural character of validation in participatory and action research.

I am aware that my proposals for reconstruction are upsetting basic assumptions of "scientificness" inherited from the Greeks and further institutionalized in the 16th and 17th century scientific revolution (Toulmin, 1990, 2001; Toulmin \& Gustavsen, 1996) based on a spectator view of knowing and a copying focus of inquiry. In mirroring reality, it is quite reasonable to stay free from values, purposes, and interests and avoid "activist" stances that participatory and action research is perceived to be using. If ultimate validation is correspondence with given reality, alternative validation tends to be seen as secondary or preliminary to this ultimate validation. That people agree on and act according to a claim may be indication of its truth, but is not really truth before correspondence has been established. But, if actionability is part of knowledge and truth as trustworthiness, then the purposes that action is to further and engagement of involved is inherent in science.

A framework for understanding purpose in science and its basis in validity, reliability, and the core characteristics of participatory and action research is developed. Participatory and action research require considering a broader spectrum of purpose. I do not claim that this framework is unique. It is offered as indicative of important domains of purpose that are as far as unavoidable to consider in scientific inquiry. I hope that the framework can support proposals in participatory and action research project development, and the judgement of "purpose worthiness" as combination and balance between 


\section{Scientific Excellence in Participatory and Action Research: Part I. Rethinking Research Quality Erik Lindhult}

different domains of purpose in a research context comprising several parties and stakeholders. "Purpose-worthiness" of research can be considered with the help of the spectrum of forms and practices of validation described in the article. The turn to action, practice, and participation enables plural ways of knowing and ways that knowledge claims can be validated and made trustworthy. This broader landscape of validation and the way participatory and action research can enable different forms of validation are described and elaborated. These forms of validation can be embedded and enabled in various research and development practices.

Both frameworks are pointing to and clarifying the broader terrain of research quality in participatory and action research, in which specific projects can be positioned to produce appropriate and high-quality achievements, and pinpoint and try to deal with quality deficiencies and risks. My aim has been to contribute to an integration with mainstream discourse through clarifying the way traditional quality concepts can be fruitfully used in an expanded framework for quality where scientific excellence of participatory and action research is visible and both participatory and action research and mainstream science approaches can be harboured. In a following article (Lindhult, 2019), reliability and objectivity and their use in participatory and action research will be clarified and the way rethinking and reconstructing these traditional quality concepts can support mainstreaming of participatory and action research in scientific community. My integrational aim is not only to clarify a specific epistemology and understanding of scientific excellence for participatory and action research but to offer it as also fruitful for the scientific community at large as an input to a wider debate on the character of scientific inquiry, scientific excellence, and research quality.

\section{About the Author}

Erik Lindhult $(\mathrm{PhD})$ is a Senior Lecturer in Innovation Management and Entrepreneurship at Mälardalen University in Sweden. He received his doctoral degree in Industrial Management from the Royal Institute of Technology in Stockholm, in the area of Scandinavian dialogue democratic approach to innovation and action research. His main area of research is participatory, collaborative, and democratic innovation and change management, as well as entrepreneurship for a sustainable development of society. His research interests also involve collaborative research methodologies, including action research and interactive research. He has been involved in a wide range of collaborative $R \& D$ projects in the private, public, and cooperative sectors, in areas such as organizational development, incubator and science park development, service innovation, societal entrepreneurship, sustainable innovation, and school development. He is a board member of the Swedish Participatory Action Research Society (SPARC) and the Swedish Interactive Research Association (SIRA), as well as an expert advisor to the EU SWAFS Horizon 2020 research committee. 


\section{Scientific Excellence in Participatory and Action Research: Part I. Rethinking Research Quality Erik Lindhult}

\section{References}

Alvesson, M., \& Sandberg, J. 2013. Constructing Research Questions: Doing Interesting Research. Los Angeles: SAGE. https://dx.doi.org/10.4135/9781446270035

Alvesson, M., \& Sköldberg, K. 2018. Reflexive Methodology: New Vistas for Qualitative Research (3rd ed.). London: SAGE Publications Ltd.

Alvesson, M., Gabriel, Y., \& Paulsen, R. 2017. Return to Meaning: A Social Science with Something to Say. Oxford: Oxford University Press.

Bacon, F. 1960. The New Organon. Indianapolis, IN: Bobbs-Merrill.

Bradbury-Huang, H. 2010. What Is Good Action Research? Why the Resurgent Interest? Action Research, 8(1): 93-109.

https://doi.org/10.1177/1476750310362435

Bradbury-Huang, H. (Ed.). 2015. The SAGE Handbook of Action Research (3rd ed). Los Angeles: SAGE.

Bradbury, H., \& Reason, P. 2001. Conclusion: Broadening the Bandwith of Validity: Issues and Choice-Points for Improving Quality of Action Research. In P. Reason \& H. Bradbury (Eds.), Handbook of Action Research. Participative Inquiry \& Practice: 447-456. London: Sage Publication Ltd.

Brown, J. R. 1996. The I in Science. Oslo: Scandinavian University Press.

Brown, L. D., \& Tandon, R. 1983. The Ideology and Political Economy of Inquiry: Action Research and Participatory Research. The Journal of Applied Behavioral Science, 19(3): 277-294. https://doi.org/10.1177/002188638301900306

Bryman, A. 2016. Social Research Methods (5th ed.). Oxford: Oxford University Press.

Checkland, P., \& Holwell, S. 1998. Action Research: Its Nature and Validity. Systemic Practice and Action Research, 11(1): 9-21. https://doi.org/10.1023/A:1022908820784

Churchman, W. 1971. The Design of Inquiring Systems: Basic Concepts of Systems and Organization. New York: Basic Books.

Clark, A. (Ed.) 1976. Experimenting with Organizational Life: The Action Research Approach. New York: Plenum.

Coghlan, D. 2016. Retrieving a Philosophy of Practical Knowing for Action Research. International Journal of Action Research, 12(1): 84-107.

Coghlan, D., \& Brannick, T. 2014. Doing Action Research in Your Own Organization. London: SAGE.

Coghlan, D., \& Shani, A. B. 2014. Creating Action Research Quality in Organization Development: Rigorous, Reflective and Relevant. Systemic Practice and Action Research, 27(6): 523-536. https://doi.org/10.1007/s11213-013-9311-y

Denzin, N. K., \& Lincoln, Y. S. 2011. The SAGE Handbook of Qualitative Research (4th ed.) Thousand Oaks, CA: SAGE.

Dewey, J. 1903/1976. Studies in Logical Theory. In J. A. Boydston (Ed.), 1976, The Middle Works of J. Dewey, 1899-1924, Volume 2 (1902-1903): 293-378. Carbondale, IL: Southern Illinois University Press. (Original work published in 1903.)

Dewey, J. 1929. The Quest for Certainty: A Study of the Relation of Knowledge and Action. New York: Minton, Balch \& Company.
Dewey, J. 1939. Logic: The Theory of Inquiry. London: George Allen \& Unwin Ltd.

Dewey, J. 1946. Problems of Men. New York: Philosophical library.

Dilthey, W. 1979. Selected Writings. Cambridge: Cambridge University Press.

Eikeland, O. 2006. Validity of Action Research and Validity in Action Research. In K. A. Nielsen \& L. Svensson (Eds.), Action and Interactive Research: Beyond Practice and Theory: 193-240. Maastricht: Shaker Publishing.

Eikeland, O. 2008. The Ways of Aristotle: Aristotelian Phronesis, Aristotelian Philosophy of Dialogue, and Action Research. Berlin: Peter Lang.

Eikeland, O. 2012. Action Research: Applied Research, Intervention Research, Collaborative Research, Practitioner Research, or Praxis Research? International Journal of Action Research, 8(1): 9-44.

Feldman, A. 2007. Validity and Quality in Action Research. Educational Action Research, 15(2): 21-32.

https://doi.org/10.1080/09650790601150766

Fals-Borda, O. 1979. Investigating Reality in Order to Transform It: The Columbian Experience. Dialectical Anthropology, 4(1): 33-56. https://doi.org/10.1007/BF00417683

Fals-Borda, O., \& Rahman, M. (Eds.). 1991. Action and Knowledge: Breaking the Monopoly with Participatory Action-Research. New York: The Apex Press.

Foucault, M. 1980. Power/Knowledge: Selected Interviews and Other Writings 1972-1977. Brighton, UK: Harvester Press.

Gaventa, J., \& Cornwall, A. 2008. Power and Knowledge. In P. Reason \& H. Bradbury (Eds.), The SAGE Handbook of Action Research (2nd ed.): 172-189. Los Angeles: SAGE. https://dx.doi.org/10.4135/9781848607934.n17

Greenwood, D. 2002. Action Research: Unfulfilled Promises and Unmet Challenges. Concepts and Transformation, 7(2): 117-139. https://doi.org/10.1075/cat.7.2.02gre

Greenwood, D., \& Levin, M. 1998. Introduction to Action Research. Thousand Oaks, CA: SAGE.

Guba, E., \& Lincoln, Y. 1989. Fourth Generation Evaluation. Newbury Park: SAGE.

Gustavsen, B. 1986. Social Research and Participative Dialogue. In F. Heller (Ed.), The Use and Abuse of Social Science: 143-156. London: SAGE.

Gustavsen, B. 1992. Dialogue and Development: Theory of Communication, Action Research and the Restructuring of Working Life. Assen/Maastricht: Van Gorcum.

Gustavsen, B. 2014. Social Impact and the Justification of Action Research Knowledge. Journal of Action Research, 12(4): 339-356. https://doi.org/10.1177/1476750314534455

Gustavsen, B. 2017. Action Research and the Promotion of Democracy. International Journal of Action Research, 13(2): 101-111.

Habermas, J. 1971. Knowledge and Human Interests. Boston, MA: Beacon Press.

Habermas, J. 1984. The Theory of Communicative Action, Vol I. London: Polity Press. 


\section{Scientific Excellence in Participatory and Action Research: Part I. Rethinking Research Quality Erik Lindhult}

Habermas, J. 1987. The Theory of Communicative Action, Vol II. London: Polity Press.

Hafting, T., \& Lindhult, E. 2013. Developing Collaborative Power in Working Life: Linking American Pragmatism and Action Research. In M. Kelemen \& N. Rumens (Eds.), American Pragmatism and Organisation: Issues and Controversies: 205-222. Surrey, UK: Gower/Ashgate.

Hall, B., Gillette, A., \& Tandon, R. 1982. Creating Knowledge: A Monopoly? Participatory Research in Development. Toronto: International Council for Adult Education.

Heidegger, M. 1962. Being and Time. New York: HarperCollins.

Herr, K., \& Anderson, G. L. 2015. The Action Research Dissertation: A Guide for Students and Faculty. Thousand Oaks, CA: SAGE.

Heron, J. 1996. Co-operative Inquiry: Research into the Human Condition. London: SAGE.

Johansson, A. W., \& Lindhult, E. 2008. Emancipation or Workability? Critical versus Pragmatic Scientific Orientation in Action Research. Action Research, 6(1): 95-115. https://doi.org/10.1177/1476750307083713

Kaplan, R. S. 1998. Innovation Action Research: Creating New Management Theory and Practice. Journal of Management Accounting Research, 10: 89-118.

Kemmis, S. 2008. Critical Theory and Participatory Action Research. In P. Reason \& H. Bradbury (Eds.), The SAGE Handbook of Action Research (2nd ed.): 121-138. Los Angeles: SAGE. https://dx.doi.org/10.4135/9781848607934.n14

Leung, L. 2015. Validity, Reliability, and Generalizability in Qualitative Research. Journal of Family Medicine and Primary Care, 4(3): 324-327.

https://dx.doi.org/10.4103/2249-4863.161306

Levin, M. 2012. Academic Integrity in Action Research. Action Research, 10(2): 133-149. https://doi.org/10.1177/1476750312445034

Lewin, K. 1946. Action Research and Minority Problems. Journal of Social Issues, 2(4): 34-46. https://psycnet.apa.org/doi/10.1111/j.1540-4560.1946.tb02295.x

Lincoln, Y., \& Guba, E. 1985. Naturalistic Inquiry. Newbury Park, CA: SAGE.

Lindhult, E. 2002. The Quality of Action Research. In Proceedings from the 2nd HSS Research Conference, May 9-11, 2001, Halmstad University, Sweden.

Lindhult, E. 2005. Management by Freedom: Essays in Moving from Machiavellian to Rousseauian Approaches to Innovation and Inquiry. Doctoral Thesis in Industrial Economics and Management. Stockholm: KTH Royal Institute of Technology.

Lindhult, E. 2008. Att bedöma och uppnå kvalitet i interaktiv forskning. In B. Johannisson, E. Gunnarsson, \& T. Stjernberg (Eds.), Gemensamt kunskapande - den interaktiva forskningens praktik. Växjö, Sweden: Växjö University Press.

Lindhult, E. 2015. Towards Democratic Scientific Inquiry? Participatory Democracy, Philosophy of Science and the Future of Action Research. In E. Gunnarsson, H. P. Hansen, \& B. Steen Nielsen (Eds.), Action Research for Democracy - Intervening in the Current Crisis: New Ideas and Perspectives from Scandinavia. London: Routledge.
Lindhult, E. 2019. Scientific Excellence in Participatory and Action Research: Part II. Rethinking Objectivity and Reliability. Technology Innovation Management Review, 5(9): 22-33. http://doi.org/10.22215/timreview/1238

MacIntosh, R., \& Bonnet, M. (Eds.) 2007. Special Issue on International Perspectives on Validity in Action Research. Management Research News, 30(5).

Marshall, J. 2016. First Person Action Research. Los Angeles: SAGE Publications.

Marti', J., \& Villasante, T. R. 2009. Quality in Action Research: Reflections for Second-Order Inquiry. Systemic Practice and Action Research, 22(5): 383-396. https://doi.org/10.1007/s11213-009-9136-X

McNiff, J., Lomax, P., \& Whitehead, J. 1996. You and Your Action Research Project. London: Routledge.

Merriam, S. B., \& Tisdell, E. J. 2016. Qualitative Research: A Guide to Design and Implementation. San Francisco, CA: Jossey-Bass.

Nielsen, K. A., \& Svensson, L. 2006. Action Research and Interactive Research. Beyond Practice and Theory. Maastricht, Netherlands: Shaker Publishing.

Nonaka, I. 1994. A Dynamic Theory of Organizational Knowledge Creation. Organization Science, 5(1): 14-37. https://doi.org/10.1287/orsc.5.1.14

Pålshaugen, Ö. 2002. Discourse Democracy at Work: On Public Spheres in Private Enterprises. Concepts and Transformation, 7(2): 141-192. https://doi.org/10.1075/cat.7.2.03pal

Reason, P. 2006. Choice and Quality in Action Research Practice. Journal of Management Inquiry, 15(2): 187-203. https://doi.org/10.1177/1056492606288074

Reason, P., \& Bradbury, H. (Eds.) 2001a. Handbook of Action Research: Participative Inquiry \& Practice. London: SAGE.

Reason, P., \& Bradbury, H. 2001b. Introduction: Inquiry and Participation in Search of a World Worthy of Human Aspiration. In P. Reason \& H. Bradbury (Eds.), Handbook of Action Research: Participative Inquiry \& Practice: 1-14. London: SAGE.

Reason, P., \& Bradbury, H. 2008. The SAGE Handbook of Action Research (2nd ed). Los Angeles: SAGE. https://dx.doi.org/10.4135/9781848607934

Reason, P., \& Torbert, W. R. 2001. The Action Turn: Toward a Transformational Social Science. Concepts and Transformations, 6(1): 1-37.

https://doi.org/10.1075/cat.6.1.02rea

Rorty, R. 1979. Philosophy and the Mirror of Nature. Princeton, NJ: Princeton University Press.

Rorty, R. 1998. Truth and Progress: Volume 3: Philosophical Papers. Cambridge: Cambridge University Press.

Santos, B. 2014. Epistemologies of the South: Justice against Epistemicide. London: Routledge.

Schön, D. 1983. The Reflective Practitioner: How Professionals Think in Action. Aldershot, UK: Avebury.

Simon, H. A. 1996. The Sciences of the Artificial (3rd ed). Cambridge, MA: MIT Press. 


\section{Scientific Excellence in Participatory and Action Research: \\ Part I. Rethinking Research Quality Erik Lindhult}

Stringer, E. 1999. Action Research (2nd ed). Thousand Oaks, CA: SAGE.

Susman, G. I., \& Evered, R. D. 1978. An Assessment of the Scientific Merits of Action Research. Administrative Science Quarterly, 23(4): 582-603.

https://doi.org/10.2307/2392581

Svensson, L., Ellström, P.-E., \& Brulin, G. 2007. Introduction - On Interactive Research. International Journal of Action Research, 3(3): 233-249.

Toulmin, S. 1990. Cosmopolis: The Hidden Agenda of Modernity. New York: MacMillan.

Toulmin, S. 2001. Return to Reason. Cambridge, MA: Harvard University Press.

Toulmin, S., \& Gustavsen, B. (Eds.) 1996. Beyond Theory: Changing Organizations through Participation. Amsterdam: John Benjamins Publishing.

Van de Ven, A. 2007. Engaged Scholarship: A Guide for Organizational and Social Research. Oxford: Oxford University Press.

Weber, M. 1978. Economy and Society, Volume I. An Outline of Interpretative Sociology. Berkeley: University of California Press.

Whyte, W. (Ed.) 1991. Participatory Action Research. Newbury Park, CA: SAGE.

Wittgenstein, L. 1984. Über Gewissheit. Werkausgabe band 8. Frankfurt am Main: Suhrkamp.

Citation: Lindhult, E. 2019. Scientific Excellence in

Participatory and Action Research: Part I. Rethinking

(cc) BY

Research Quality. Technology Innovation Management

Review, 9(5): 6-21.

http://doi.org/10.22215/timreview/1237

Keywords: action research, participatory research, quality 


\section{Academic Affiliations and Funding Acknowledgements}
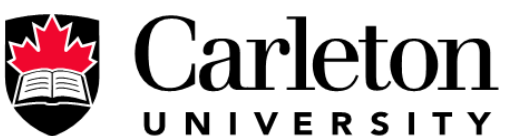

U N I V E R S I T Y

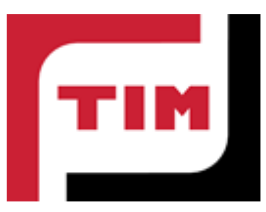

Technology Innovation Management (TIM; timprogram.ca) is an international master's level program at Carleton University in Ottawa, Canada. It leads to a Master of Applied Science (M.A.Sc.) degree, a Master of Engineering (M.Eng.) degree, or a Master of Entrepreneurship (M.Ent.) degree. The objective of this program is to train aspiring entrepreneurs on creating wealth at the early stages of company or opportunity lifecycles.

- The TIM Review is published in association with and receives partial funding from the TIM program. 